\title{
QUESTIONING THE EFFECTIVENESS OF THE EU'S EUROPEAN NEIGHBOURHOOD POLICY: THE CASE OF UKRAINE
}

\author{
Pınar AKGÜL*
}

\begin{abstract}
With the post-Cold War enlargement processes, the EU closed to an enlarged neighbourhood. This new neighbourhood stretches from the southern Mediterranean to Eastern Europe as well as South Caucasus where various priorities as well as security challenges exist. Therefore, this new borderline increases the requirement to form new neighbourhood policies covering entire areas for the EU. The European Neighbourhood Policy (ENP) was formed in accordance with these concerns. However, accepting these areas as similar, and so adapting one-size-fits-all policy approaches, questions the efficiency of the initiative. This essay argues that the EU has not been able to achieve what it wanted with the ENP because of a lack of common attitude and the reluctance of current member states, as well as conditionality. These problems cause an ambiguity of the EU initiative. These ambiguities and inefficiencies can be analysed through the case of Ukraine, since it has made great steps to fulfil EU conditions, but has not got what it desires the most; full membership.
\end{abstract}

Keywords: European Union, Ukraine, European Neighbourhood Policy

JEL Codes: F50, F53, F55

\section{AB'NIN AVRUPA KOMŞULUK POLITIKASININ ETKINLIĞİNIN SORGULANMASI: UKRAYNA ÖRNEĞINDE}

ÖZET

Soğuk Savaş sonrası genişleme süreçlerinden bu yana AB daha geniş bir coğrafyaya komşu olmuştur. Bu yeni coğrafya farkl öncelikleri ve güvenlik sorunları olan güney Akdeniz'den Doğu Avrupa'ya ve Güney Kafkaslara kadar uzanmaktaydı. Bu yeni sını AB için tüm alanı kapsayacak bir komşuluk

\footnotetext{
* Öğretim Görevlisi Dr., Giresun Üniversitesi, pinar.akgul@giresun.edu.tr, Orcid: 0000-0001-8184-3103

Makale Geçmişi/Article History

Başvuru Tarihi / Date of Application : 09 Şubat 2021

Düzeltme Tarihi / Revision Date : 21 Mart 2021

Kabul Tarihi / Acceptance Date : 22 Mart 2021
}

Araştırma Makalesi/Research Article 
politikasının kurulması ihtiyacını doğurmuştur. Avrupa Komşuluk Politikası bu ihtiyaçlar doğrultusunda kurulmuş bir inisiyatiftir. Her devleti aynı kabul etmesi ve bu nedenle de aynı politikalar yöneltmesi ise inisiyatifin başarılı olup olmadı̆̆ sorularının çıkmasına neden olmuştur. Bu çalışmada $A B$ bu inisiyatifle dilediği başarıyı ele edememiștir argümanı savunulacaktır. Bu başarısızlı̆̆ın nedenleri olarak ise AB üyesi devletler arasindaki ortak hareket etme eksiliği, üyelerin isteksizlikleri ve şartlllık politikası üzerinde durulacaktır. Bu problemler AB inisiyatifinin belirsizliğine yol açmıştır sonucu çıkarılacaktır. Bu argüman Ukrayna örneği üzerinden analiz edilecektir. Ukrayna'nın seçilmesinin nedeni inisiyatifin belirsizliğine ve etkisizliğine vurgu yapabilmek açısından her ne kadar AB'nin şartlarını yerine getirse de çok istediği tam üyeliği alamamış olmasından kaynaklanmaktadır.

Anahtar kelimeler: Avrupa Birliği, Ukrayna, Avrupa Komşuluk Politikası

JEL kodlarl: F50, F53, F55

\section{INTRODUCTION}

After enlargement in 2004 and 2007, the European Union's (EU) borders reached the Mediterranean in the south, Russia in the north and the Black Sea in the east. As a result of such enlargement, the EU not only now has to deal with new member states' economic and social problems, such as low living standards or fragile political systems, but also to consider new neighbours who pose a potential risk to stability and security. To the east, the EU has to deal with democratic transitions, to the north, Russia and its national interests, and to the south, security issues, such as radical terrorism figure among its main concerns (Emerson et al., 2007). As a result, the EU realises the importance of its neighbours. Therefore, a considerable number of scholars have focused on the EU's policies towards its neighbours, and their main concern is whether these policies are effective or not (Smith, 2005; Del Sarto and Schumacher, 2005; Whitman and Wolff, 2010; Grant, 2011).

The European Neighbourhood Policy (ENP) has been in existence since 2003, with its main concern being '[...] to avoid drawing new dividing lines in Europe and to promote stability and prosperity within and beyond the new borders of the Union' (COM, 2003a: 4). Therefore, the EU's main purpose is to develop a 'ring of friends' with its neighbours, yet without an accession perspective (Whitman and Wolff, 2010). How should these definitions be conceptualised? Do they mean putting neighbours on the outside or offering the prospect of a stake in the EU's internal market? When the ENP began, it was designed to achieve two objectives; to spread stability, security and prosperity within the EU's neighbourhood, so as to mitigate the risks of instability which would affect the EU's borders and also to prevent a feeling of exclusion among its neighbours. However, the effectiveness of these objectives has become questioned (Emerson et al., 2007; Whitman and Wolff, 2010; Grant, 2011). Scholars argue that it is not effective, due to the ambiguity of the ENP policies (Edwards, 2008; Smith, 2005; Solonenko, 2006). Furthermore, the ENP has failed to achieve all of these goals (Whitman and 
Wolff, 2010). The reason for this could be the reluctance of EU member states towards its neighbours, in terms of short-term policies or a lack of substantial incentives (Whitman and Wolff, 2010). As a consequence of this, the EU is still close to unstable neighbours.

In light of this issue, this essay argues that the ENP is not effective in dealing with its neighbours. The first problematic issue is the ENP itself. The ENP has a lack of common ground because it consists of different countries from different regions, each with different priorities and each being subject to different problems. Therefore, generalising problems and offering one-size-fits-all solutions could not meet the expectations of ENP states (Akgül, 2020). The second problematic issue is that conditionality plays a crucial role in determining and pursuing its policies (Del Sarto and Schumacher, 2005; Smith, 2005; Emerson et al., 2007). There are often conditions directed by the EU that ENP states are expected to fulfil. However, even though states fulfil these conditions, they are not be able to get an opportunity to achieve full EU membership. The reasons for these problems are a lack of political will and member states' reluctance towards dealing with their neighbours (Whitman and Wolff, 2010). Short-term practical options, such as visa facilitation and lack of incentives, can be given as examples in the context of this issue. Therefore, the ENP has not responded to neighbour states' expectations, as with Ukraine, for example. In the context of these issues, this essay is divided into two parts. First, after giving the background of the ENP, so as to illustrate its problematic structure, this essay critically engages the reasons for its ineffectiveness, and in this context this essay asserts the ambiguities of ENP policies. Second, in order to support its argument, this essay focuses on the inefficiencies of the ENP policies using the example of Ukraine. The rationale for choosing Ukraine is, in particular after the Orange Revolution, that Ukraine wants to become a member of the EU, and this ambition is supported by a number of EU members. It is expected that the ENP would be clear in precluding Ukraine from becoming a full member, but ENP policies could not preclude it. With regard to these reasons, this essay concludes that the ENP is not effective in dealing with the EU's neighbours. A limitation of this essay is that it only focuses on the ENP, and does not consider later policies, namely the Black Sea Synergy and the Eastern Partnership.

\section{THE EUROPEAN NEIGHBOURHOOD POLICY (ENP)}

The origins of the ENP date back to early 2002 with the United Kingdom (UK) former foreign minister Jack Straw's letter to his Spanish colleague in May. However, his 'wider Europe' initiatives only considered Belarus, Ukraine, Russia and Moldova, but in December 2002, the European Council approved the UK's 'wider Europe' initiative and also added southern Mediterranean countries with the final version being constituted in 2004 with Caucasian republics (Smith, 2005; Edwards, 2008). Yet Russia preferred to develop co-operation with the EU on an equal basis, and therefore four common spaces were set forth: economic; freedom, security and justice; external security; and research and 
education. In the context of this issue, the EU clearly makes a distinction between who its neighbours are and who they are not, which means that this new neighbourhood policy excludes candidate countries, including Turkey, Romania, Bulgaria and countries of the western Balkans (COM, 2003a). On the other hand, the ENP is directed towards the sixteen closest neighbours; namely Algeria, Armenia, Belarus, Egypt, Georgia, Israel, Jordan, Lebanon, Libya, Moldova, Morocco, Occupied Palestinian Territory, Syria, Tunisia and Ukraine. However, only twelve of these agreed to its Action Plans. The ENP 'is not yet fully activated for Algeria, Belarus, Libya and Syria, since these have not agreed the Action Plans' (ENP website, 2010).

The EU's main concern is being surrounded by well-governed states, and therefore, the importance of the neighbourhood policy has been at the highest level (Emerson et al, 2007; Smith, 2005; COM, 2003b). However, when looking at the EU neighbourhood, it consists of various types of problematic states which potentially affect the EU itself. One salient issue that the new neighbourhood brings is their security problems. In 2003, the European Security Strategy stressed that 'neighbours who are engaged in violent conflict, weak states where organised crime flourishes, dysfunctional societies or exploding population growth on its borders all pose threats for Europe' (2003b: 7). Therefore, creating a stable and secure neighbourhood, as well as considering its own stability and security, are salient factors of the establishment of the neighbourhood policy.

The 'vision' of the ENP was, therefore, to establish 'a ring of countries, sharing the EU's fundamental values and objectives, drawn into an increasingly close relationship, going beyond cooperation to involve a significant measure of economic and political integration' (COM, 2004: 4; Edwards, 2008: 47). The motto is 'by helping our neighbours, we help ourselves' (Whitman and Wolff, 2010: 7). Policies range from different areas as stated in the ENP (COM, 2004: 3):

The privileged relationship with neighbours will build on mutual commitments to common values, principally within the fields of the rule of law, good governance, respect for human rights, including minority rights, the promotion of good neighbourly relations, and the principles of market economy and sustainable development.

Regarding this, the ENP presents a multilateral policy including all neighbours which are not candidate states, and the Action Plans are the main policy documents to develop relationships with them. The Action Plans have some similarities to European Agreements, which map the enlargement policy. These consist of priorities, which include the following: a commitment to shared values; a more effective political dialogue; economic and social development policy; trade and internal markets; justice and home affairs; connecting the neighbourhood; and people-to-people programmes and agencies (Whitman and Wolff, 2010: 7). However, these do not offer membership, but an alternative membership. As stated in December 2002 by Commission President Romano Prodi, the new neighbourhood concept would 'offer more than partnership and less than membership, without precluding the latter' (2002:5). 
Since its foundation, the ENP has been revised twice. The first time was in 2011, following the Arab Spring and the second was in 2015. The former brought additional reform efforts by partner countries which would be rewarded with additional financial and other support; the so-called 'more and more' principle (EEAS, website 2016a). In the latter, the aim was to build a more effective partnership between the EU and its neighbours towards a more stable EU neighbourhood, and the revised ENP sets three joint priorities for cooperation; economic development for stabilisation, security, and migration and mobility (EEAS website, 2021). Differentiation amongst partner countries was accepted as one of the key principles of the revised ENP. Partner countries could also access the EU's market and regulatory framework, standards and internal agencies and programmes (EEAS website, 2016a).

Considering the Commission documents or the President's speech, it appears that the ENP is extremely clear regarding its targets. The main priorities include enhancing relationships with neighbours and ensuring that they are as well-governed as possible. In the context of this issue, neighbour states should consider the EU's values and participate in economic and political integration. However, when it comes to pursuing all these priorities, the ENP has certain ambiguities (Edwards, 2008; Smith, 2005). In general terms, 'the ambiguity regarding the EU's intentions in the neighbourhood extends to the mechanisms employed to encourage political and economic change in the partner countries' (Emerson et al., 2007: 6). In the case of the Action Plans, which were first published by the Commission in 2004, it put these priorities to neighbour states as 'things to do'. However, it is not clear how they provide a 'real intensity for reform' (Smith, 2005: 764). Moreover, in terms of who is the object and who is the subject is not very well-demonstrated in them. In addition, the notion as to which programmes and policies partner countries can participate in, and when, is vague and illusive and not clearly stated (Whitman and Wolff, 2010).

Furthermore, the EU appears to have reserved the logic of conditionality, not offering a carrot from the outset, but considering offering the possibility of some form of deeper relationship (Whitman and Wolff, 2010). In 2004, a strategy paper stated that, 'The EU does not seek to impose conditions or priorities on its partners', but nevertheless, it is essential to be aware of the shared values and joint interests for neighbour states (COM, 2004: 8). The EU emphasises 'joint ownership', on the one hand requiring negotiation of the Action Plans, and on the other 'to compensate the EU could build stronger alliances on the matter of policy conditionality between its budgetary instruments' (Emerson et al., 2007: 6). In a 2011 Commission document, the EU states that its support to its neighbours is conditional and depends on progress in building and consolidating democracy and respect for the rule of law (COM, 2011). When the state fulfils these requirements, it could receive economic support, such as funding for social and economic development or greater market access and facilitation of mobility. In the context of this issue, therefore, the ENP does not offer its neighbours a membership, and so can be defined as soft conditionality, but does not clarify, however, if neighbour states complete these conditions what the ENP offers next (Tonra, 2010). 
Finally, sending a message from the EU to neighbour states of that the ENP might also be problematic. For instance, one of the criteria of the neighbourhood concept is pre-accession conditions like candidate states, such as considering acquis, but the problem is in Commission reports and also speeches which state that the new neighbourhood policy will not predict membership. However, if the ENP is not a guaranteed membership, it can be asked why neighbour states want to volunteer for it. Smith (2005) points out that the EU has not dashed the hopes of any neighbour states' membership (Morocco excepted); in other words, it has not said 'no' permanently. Therefore, it is open to different perspectives from neighbouring states. Rather than the Mediterranean states, the eastern European and southern Caucasian states declare their priorities as becoming members of the EU (Edwards, 2008). However, the EU itself is problematic in this regard due to not pursuing any effective policy. The main aim of the EU is not to enlarge so far, but neighbour states have membership desires and so they lost their ambition to implement what the ENP offers them (Whitman and Wolff, 2010).

\section{THE CASE OF UKRAINE}

As stated above, even though the EU did not offer a full membership for the ENP countries, due to its ambiguities, the ENP is not effective in implementing what it offers. A number of neighbour states, such as Moldova, Ukraine and Georgia, on the other side, declare their priorities to be members of the EU (Emerson et al., 2007). In relation to this issue, the ENP's ineffectiveness in advancing EU-Ukraine relations can serve as an example. Ukraine was one of the states mentioned in the British and Danish foreign ministers' New Neighbourhood Initiative (Solonenko, 2006), and then in the wider European Neighbourhood concept. Moreover, in terms of demonstrating neighbour states' attitudes, Ukraine is a good case study, due to the fact that as Emerson et al. state (2007), Ukraine is a positive or willing country in pursuing the Action Plans and so took the EU's implementations seriously.

In the case of Ukraine, two different approaches are evident. One, from before the Orange Revolution, displays its rejection to the 2004 Action Plans from a high-level political perspective. Indeed, it planned not to ratify the Action Plans due to not wanting to be in the same position as Mediterranean states (Solonenko, 2006). The other is after the Orange Revolution, when the political elite declared EU membership to be a priority, and therefore focused more on the membership issue. As a summary, while for Kuchma administration (before the Orange Revolution) the ENP was seen as a foreign policy tool, and so it was rather pragmatic. Both the EU and Ukraine use the term strategic partnership, yet it rather refers to 'determinant regional actor' (Ferreira-Pereira and Vieira, 2015). After the Orange revolution, Ukrainian political elites realised the importance of making reforms on domestic politics, which would help them to become members of the EU, and so regulated their policies accordingly.

The Ukraine-EU relationship started with the collapse of the Soviet Union and the independence of Ukraine. Not only Ukraine, but also other post-Soviet countries have become a new policy area for 
the EU, aiming to play an active role in their political and economic integration and stability, in such fields as democracy, market economy, the rule of law and respect of human rights (Ferreira-Pereira and Vieira, 2015). In this regard, Ukraine and the EU signed a Partnership and Cooperation Agreement (PCA) on 14 June, 1994, just ten days after a PCA between Russia and the EU. This dialogue continues with the adoption of the Common Strategy towards Ukraine (CSU) in 1999, putting Ukraine in an exclusive category of states that the EU aims to develop a more solid relationship with, based on shared values and common interests (Ferreira-Pereira and Vieira, 2015). The content of the bilateral relationship has begun to be seen as a strategic partnership after this agreement. All these positive developments were interpreted by Ukrainian elites as Ukraine becoming a candidate country, leading to future EU membership, but as indicated below it could only bring a neighbourhood.

After the enlargement in 2004, Ukraine became important for the EU. This is because the EU's border had reached the country, and so the stable and secure Ukraine had now become one of greatest targets of the EU. The first Action Plans, signed in 2005, for three years, included a long list of priority areas, from social and legal legislation to economic and security concerns. In order to monitor these priority areas, the EU structured a body under the PCAs, 'without providing further details on benchmarks, timing and follow-up' (Sasse, 2008: 307). In fact, the EU's ambiguities are more visible after this. Following the Orange Revolution, Ukrainian political elites expected important developments in their relationship with the EU. This is because the new government had pro-European and proAtlantic aims and, related to these, it volunteered to adjust its policies accordingly. However, the EU side was reluctant to renegotiate the Action Plans or offer them full membership; on the contrary, the EU added ten new points to the Action Plans. In fact, the substance of the Action Plans did not change, and so this may just be conceptualised as a 'goodwill gesture' from the EU and could prevent Ukraine from becoming member (Sasse, 2008: 208). A year later, the EU singled out the opening of negotiations on visa facilitation and policies related to energy, border control and market economy.

In April 2005, Ukraine formulated the 'Road Map', which has 'remained the main attempt to streamline the measures required under the Action Plans and assign them to specific executive agencies' (Sasse, 2010: 185). The EU, on the other side, created a new Association Agreement in 2008, which has certain similarities with the Europe Agreement in Central and Eastern Europe of the 1990s, and the Association Agreement in the western Balkans (Sasse, 2010). It focused on 'deep free trade and a longterm perspective for a visa-free regime between the EU and Ukraine, but avoided direct references to potential membership' (Sasse, 2010: 188). From the Ukrainian side, this agreement appeared to offer an 'explicit membership perspective' (Sasse, 2010: 189). However, this agreement has two meanings; while on the one hand, it implies Ukrainian membership, on the other, it only presages an important step in Ukraine-EU relations. Nonetheless, this new agreement caused new hopes among Ukrainian political elites, because Ukraine was the first neighbour state to be offered this sort of agreement by the EU. In fact, the new agreement is not clear whether, if Ukraine were to fulfil the conditions, it would be difficult 
for the EU to reject Ukrainian EU membership in the long run (Sasse, 2008). These ambiguities led to disappointment from Ukrainian public opinion as well as the elites and, in the 2010 elections, the proRussian leader Yanukovych was elected.

In 2014, the last Association Agreement, and a Deep and Comprehensive Free Trade Area (DCFTA) between Ukraine and the EU, was signed and came into force in September, 2017. In particular, the 2013-2014 civil protests at Independence Square (the Maidan) ${ }^{1}$ and the Russian annexation of Crimea and its aftermath were key developments putting the performance of the EU with Ukraine to an extremely difficult test. Signing the Association Agreement, according to Ferreira-Pereira and Vieira (2015) and Pridham (2014), was an important signal of EU support for Ukraine's European decision. This agreement, was based on shared values and commitment to respect democratic principles, the rule of law, good governance, human rights and fundamental freedoms. It brings the two sides closer and aims to promote 'deeper political ties, stronger economic links and respect for common values' (EEAS website, 2020). The DCFTA offers Ukraine a framework for modernising its trade relations and for economic development by opening up markets and harmonising laws, standards and regulations in various sectors (EEAS website, 2016b). It also aims to further economic integration and political association between the sides. Moreover, there was reference to the recognition of Ukraine as a European state, sharing a common history and values with other EU member states, and also welcomed Ukraine's European choice. However, these new agreements mention neither Crimea nor any other conflict regions, where in fact lies the essential problem for both Ukraine and the EU (COM, 2014). Russia's illegal settlement in Crimea was not even condemned by the EU then. Condemnation was only mentioned in the 2014 Progress Report indicating the EU's support of Ukrainian territorial integrity and sovereignty (COM, 2015).

Considering these Action Plans and Association Agreements, it is clear that there is a deep expectation gap between the EU and Ukraine. For the EU, it is the security and stability of its border and the prevention of any threats coming from there, whereas for Ukraine, it is seen as a new foreign policy purpose strengthening its global image. However, both sides, but in particular Ukraine, have to face great disappointment. The first disappointment for Ukraine is that it criticises the wide policy area of the ENP and does not want to be considered in the same realm of policy concern as the Mediterranean states or Morocco (Solonenko, 2006). This is because, even though these countries do not have any priorities on being members of the EU, Ukraine's priority is EU membership. For instance, in the signature ceremony of the 2014 Association Agreement, newly-elected President Poroshenko

\footnotetext{
${ }^{1}$ The Maidan protests began with the Ukrainian President Yanukovych's refusal to sign the EU Association Agreement in 2013. On February, 2014, the President and opposition reached an agreement and, subsequently, parliament voted for a law to reinstate the 2004 constitution. 'Following the sudden departure of President Viktor Yanukovych from Kiev, parliament, with the necessary constitutional majority, dismissed President Yanukovych for failing to perform his duties, and appointed a new government headed by Prime Minister Arseniy Yatsenyuk. Petro Poroshenko was elected President of Ukraine on 25 May 2014. Following parliamentary elections of 26 October 2014, a new government led by Prime Minister Yatsenyuk was formed on 3 December, on a reform platform' (COM, 2015).
} 
underlined Ukraine's 'sovereign choice in favour of future membership of the EU' (Pridham, 2014: 53). Therefore, this categorisation was interpreted by the Ukrainian elites as the EU's reluctance to accept Ukraine as a member state. Consequently, rather than taking the policy implementations of EU Action Plans as a long-term priority, for Ukraine those provide only short-term and mid-term advantages. In other word, Kiev utilised these as tools for regulating internal politics and ensuring economic transformation. This ensures great improvements in implementing Action Plans, which puts Ukraine ahead of other ENP states. However, this still does not provide any opportunities for the country.

A second disappointment, in fact, relates to the EU itself. It has demonstrated certain disagreements in terms of recognising Ukraine as a candidate state, while some states, such as Poland and Sweden, support Ukrainian membership; France, by contrast, resists it (Emerson et al., 2007). This reflects on political implementation of the ENP as a problem. The problem of the ENP is that 'since its inception, the far-reaching benefits on offer have remained in the realm of possibilities' (Whitman and Wolff, 2010: 12; emphasis in the original), but in practice it has only offered modest gains to neighbours. The main ENP proposals are short-term, practical benefits, such as visa facilitation or financial assistance, but in practice these are often costly, depending on conditions. Therefore, the ENP incorporates ineffectiveness, the reasons for this perhaps being reluctance of the EU member states and vagueness of the EU itself (Sasse, 2008; Whitman and Wolff, 2010; Smith, 2005).

The third disappointment is the vagueness of Action Plans, Association Agreement; overall, the ENP itself. These, in most cases, resemble the EU accession process (Sasse, 2010). Visa facilitation could be given example of this. In 2003, a Commission document stated four freedoms; namely, free movement of persons, goods, services and capital (COM, 2003a). From the Ukrainian side, in particular, free movement of persons refers to visa facilitation. After the Orange Revolution, Ukraine assumed that this visa facilitation would be open to all Ukrainians (Barbé and Johansson-Nogués, 2008), but it was not. In 2007, the EU-Ukraine visa facilitation agreement made a list giving a right to free movement of persons, such as students and journalists. Finally, on 11 June 2017, visa-free travel for Ukrainian citizens with bio-metric passports entered into force. However, it does not give the right to work in EU member states or permanent residence (EEAS website, 2016c). In terms of the Association Agreement, even though it resembles European Agreements signed with post-Communist countries from Central and Eastern Europe that joined in 2004, the one signed with Ukraine has not been recognised by the EU as an intermediate stage towards full membership (Pridham, 2014).

The fourth disappointment is that the EU is not be able to become an alternative or a guarantor of security against Russia in Ukrainian security concerns. Russia is Ukraine's largest neighbour and it has strong influence on its domestic politics. The aim of Ukrainian elites is to ensure a balance with Moscow and so declare its fundamental foreign policy target to be members of both the EU and NATO. However, in particular, the founding EU member states have close political and economic and, in particular, energy 
relationships with Russia, and so they do not want to risk these relationships. This, therefore, risks Ukrainian political concerns. For instance, the pro-European Orange Revolution could not find strong support from the EU. This reflected on the success of the newly-elected Ukrainian government, and left under pressure from Russia. As a result of this, a pro-Russian government formed and it refused the Association Agreement in 2013.

In particular, strong Russian influence on Ukrainian domestic politics and the utilisation of Russian minorities living there, illustrated itself strongly as tools in various activities. The salient example is the Russian annexation of Crimea in 2014. On 20 March, 2014, the EU strongly condemned the illegal annexation of Crimea and Sevastopol by Russia. It declared the Russian annexation as a 'deliberate destabilisation of a neighbourhood country' and adopted a 'non-recognition policy'. In this regard, it imposed restrictive measures, or sanctions ${ }^{2}$, against the country. Such restricted measures consisted of: 'diplomatic measures; individual restrictive measures; restrictions on economic relations with Crimea and Sevastopol; economic sanctions; and restrictions on cooperation' (EU Council website, 2020). Since 2014, the EU continues to condemn Russia's illegal annexation of Crimea in every platform and does not recognise it. The EU based its defence on the United Nations General Assembly Resolution 68/262, 'Territorial integrity of Ukraine'. Moreover, it has extended the sanctions several times since then (EEAS website, 2020). Even though the EU pursues an active and assertive policy towards the Crimean case, it nevertheless indicates certain weaknesses. One salient weakness was that these sanctions could not stop Russian annexation of Crimea; on the contrary, Russia continued its assertive foreign policy in Ukraine.

Furthermore, growing Russian influence on Ukraine over its eastern regions which were dominated by Russian minorities, namely the Donestk and Luhansk regions, triggered tension between the two countries. The EU's approach there has been 'to combine pressure through restrictive measures with diplomatic efforts and continuing dialogue' (EEAS website, 2020). In this regard, it supports a peaceful and sustainable solution for easing the conflict in eastern Ukraine. The EU imposed diplomatic restrictions, sanctions against Russia and asked Moscow to implement the requirements of the Minsk agreements. As a part of ensuing political solution, the EU has stepped up its assistance to the

\footnotetext{
${ }^{2}$ In terms of diplomatic measures, the EU-Russia summit was cancelled and EU member states decided not to hold regular bilateral summits. Moreover, instead of the G8 summit in Sochi, a G7 meeting was held in Brussels on 4-5 June, 2014. In terms of restrictive measures in response to the illegal annexation of Crimea and Sevastopol, the Council imposed substantial restrictions on economic relations with these two regions. These included an import ban on goods from Crimea and Sevastopol, a full ban on investments along with a prohibition to supply tourism services in Crimea, and the banning of exports of further key goods for certain sectors, including equipment for the prospection, exploration and production of oil, gas and mineral resources. The EU imposed economic sanctions targeting exchanges with Russia in specific economic sectors: this included limiting access to primary and secondary EU capital markets; imposing an export and import ban on trade arms; establishing an export ban for dual-use goods for military use; and curtailing Russian access to certain sensitive technologies and services that could be used for oil production and exploration. Asset freezing and travel/visa bans were applied to persons and entities responsible for action against Ukraine's territorial integrity. The measures concerning economic cooperation include the European Investment Bank being requested to suspend the signature of new financing operations with Russia, and the implementation of EU bilateral and regional cooperation programmes with Russia being re-assessed with certain programmes suspended (EEAS website, 2015; 2020).
} 
Organisation for Security and Co-operation in Europe (OSCE) and contributes to the OSCE Special Monitoring Mission which monitors the implementation of the Minks agreements (EEAS website, 2020).

Finally, the situation in the Sea of Azov is an important concern for the EU, in particular regarding Russia's violations of international law. It asks Russia to provide unhindered and free passage of all ships through the Kerch Strait to and from the Sea of Azov regarding international law. In particular, incidents on 25 November, 2018, the seizure of Ukrainian vessels and their crew by Russia increases worries of potential tensions taking place at the Kerch Strait. Until their release on 7 September, 2019, it had a severe negative effect on regional stability as well as on Ukraine's territorial integrity and independence (EEAS website, 2020).

With these internal problems, it can be argued that Ukraine has been in a prominent problem for offering up its territorial integrity and independence. Solving these problems peacefully and establishing a stable Ukraine is not only important for the Ukraine itself, but also for the EU. Therefore, these developments forced the EU to become involved in the problems. However, it should be noted that these are not successful policies or initiatives; on the contrary, tensions and conflicts continue and remain in Ukraine. They also are soft security tools, such as contributing to a monitoring mission. Dekanozishvili (2020) argues that these are to avoid confrontation with Russia, due to their heavy dependence on it. As a result, it can be said that the EU has to be more assertive in ensuring Ukraine's territorial integrity and sovereignty, and so implement more assertive policies.

Overall, accepting the fact that the EU did not officially offer full membership to Ukraine, but it still maintained its membership expectations, so the attitude of the country might be criticised. However, since feeling threatened by its neighbours, in particular by Russia, the current political agenda allowed Ukraine to preserve its membership expectations. This is because maintaining a relationship with the EU might provide security, stability and development for itself. Therefore, contrary to other ENP countries, the initiative was taken seriously by Ukraine. This is because it was believed that the ENP could accelerate Ukraine's main target of becoming an EU member state; its basic strategic objective. However, ambiguities within the EU, the vagueness of the ENP and the reluctance of EU member states to accept Ukraine as a member state cause Kiev great disappointment. For instance, the Action Plans could only provide short-term opportunities: such as EU support for Ukraine's World Trade Organisation (WTO) accession; the granting of Market Economy Status; visa facilitation; EU assistance on fields such as democracy; the rule of law; legislative approximation; support in strengthening civil society; and additional funding from the European Investment Bank (Solonenko, 2006). Clearly, these were all reforming for Ukraine's domestic politics, but had no impact on its possible EU membership. Therefore, the ENP became 'disappointing, creating uncertainties and limiting incentives for reforms' for Ukrainians (Edwards, 2008: 29). 


\section{CONCLUSION}

This essay analyses whether the ENP has been effective or not in dealing with its neighbours, in addition to reasons behind the EU's effective or ineffective policies. It does so by using Ukraine as a case study of an EU neighbour state and one of states of the ENP. Ukraine was chosen because it is a good example to support this essay's argument regarding the ineffectiveness of the ENP.

Although the main aim of the ENP is to foster a 'ring of friends' of well-governed neighbours from Morocco to Moldova, due to its ambiguities, the ENP cannot be effective. It does not meet the expectations of neighbour states and this creates a reluctance on both sides. In particular, neighbour states, such as Ukraine, Moldova and Georgia, expect to become EU members, with full visa facilitation; the EU on the other hand focuses more on how to harmonise neighbour states' regulations to its acquis. In fact, the EU does not pursue a clear policy towards its neighbours. For instance, if a neighbour state fulfils the conditions set forth by the ENP, its future is not clear in terms of whether it will become a member of the EU or not. As a result, these policies have been ineffective.

This conclusion has been explained through the example of Ukraine, which has displayed different approaches towards the ENP. First, it was opposed to joining the ENP due to its unwillingness to be in the same position as Mediterranean states. Then, in particular, after the Orange Revolution, it declared membership of the EU as its priority. However, a number of the member states are reluctant to support its membership.

When the ENP was first brought into being, the EU's main purpose was to ensure the inclusion rather than the exclusion of its neighbours in order to avoid creating dividing lines between itself and these neighbours (Dannreuther, 2006). Moreover, it constituted an alternative of membership which 'was designed to spread prosperity, stability and security in the EU's new neighbourhood' (Whitman and Wolff, 2010: 6). However, as Smith (2005) states, the ENP in fact established dividing lines between the two sides. A reason for this could be reluctance on the part of the EU. In fact, theoretically, it is expected for the EU to be effective. However, it essentially prefers to offer short-term practical options, such as visa facilitation, but as in the case of Ukraine, this is not really effective (Whitman and Wolff, 2010). The problem of the ENP is that it does not decisively implement what it offers to its neighbours, and so situations regarding neighbour states are becoming worse.

Nevertheless, even if the EU's policies towards its neighbours are ineffective, it should continue its policies in order to learn from its mistakes; the Union for the Mediterranean and Eastern Partnership are good examples. Moreover, this would be beneficial for both sides. Accepting the fact that ENP partner countries have been struggling with political problems, they nevertheless do not have similar 
priorities. Therefore, as with the Union for the Mediterranean and Eastern Partnership, the EU should redesign its instruments and, in this way, it could be more assertive in its political movements. On the other hand, neighbour states should contribute to the EU's attempts and harmonise their governance and other problematic areas where they mostly face criticism in the Action Plans. As a result of compromise on both sides, effective bilateral relations may be possible, leading to smooth future relations.

\section{BIBLIOGRAPHY}

Akgül, P. (2020) The Criticism of EU's Efficiency in Region Politics: A Case Study of the Black Sea Region, Ankara, Sonçă̆ Akademi.

Barbé, E. \& Johansson-Nogués, E. (2008) "The EU as a modest 'force for good': the European Neighbourhood Policy", International Affairs, 84(1):81-96.

Commission of the European Communities, Communication from the Commission to the Council and the European Parliament, "Wider Europe-Neighbourhood: A New Framework for Relations with our Eastern and Southern Neighbours, COM (2003a) 104 final, Brussels.

Council of European Union (2003b) "European Security Strategy", http://register.consilium.europa.eu/pdf/en/03/st15/st15849.en03.pdf (12.03.2012)

Commission of the European Communities, Communication from the Commission "European Neighbourhood Policy Strategy Paper”, COM (2004) 373 final, Brussels.

Dannreuther, R. (2006) "Developing the Alternative to Enlargement: The European Neighbourhood Policy", European Foreign Affairs Review, No:11: 183-201.

Dekanozishvili, M. (2020) “The European Union's credibility-expectations gap in its European Neighbourhood Policy: perspectives from Georgia and Ukraine", Southeast European and Black Sea Studies, 20(2): 1-16.

Del Sarto, R.A. \& Schumacher, T. (2005) "From EMP to ENP: What's at stake with the European Neighbourhood Policy towards the Southern Mediterranean?", European Foreign Affairs Review, No:10: 17-38.

Edwards, G. (2008) "The Construction of Ambiguity and the Limits of Attraction: Europe and its Neighbourhood Policy”, Journal of European Integration, 30(1): 45-62.

European Union Council website (2020) "EU restrictive measures in response to the crisis in Ukraine" https://www.consilium.europa.eu/en/policies/sanctions/ukraine-crisis/ (14.03.2021).

European External Action Service (EEAS) website (2015) "In focus: EU restrictive measures in response to the crisis in Ukraine", 
http://eeas.europa.eu/delegations/russia/press corner/all news/news/2015/20150219 en.htm $(15.05 .2015)$

EEAS website (2016a), "European Neighborhood Policy (ENP)" https://eeas.europa.eu/diplomaticnetwork/european-neighbourhood-policy-enp/330/european-neighbourhood-policy-enp_en (05.01.2021).

EEAS website (2016b) "Ukraine and the EU", https://eeas.europa.eu/delegations/ukraine/1937/ukraineand-eu_en (05.01.2021).

EEAS website (2016c) "Study in the EU and travel between the EU and Ukraine", https://eeas.europa.eu/delegations/ukraine/1939/study-eu-and-travel-between-eu-and-ukraine_en (05.01.2021).

EEAS website (2020) "EU-Ukraine relations - factsheet", https://eeas.europa.eu/delegations/ukraine/4081/eu-ukraine-relations-factsheet_en (05.01.2021).

EEAS website (2021), "European Neighborhood Policy (ENP)" https://eeas.europa.eu/diplomaticnetwork/european-neighbourhood-policy-enp/330/european-neighbourhood-policy-enp_en (12.03.2021).

Emerson, M., Noutcheva, G. \& Popescu, N. (2007) "European Neighbourhood Policy Two Years on: Time indeed for an 'ENP plus"', CEPS Policy Brief, No:126: 1-28.

European Commission (2010) "The Policy: What is the European Neighbourhood Policy?", http://ec.europa.eu/world/enp/policy en.htm (18.03.2012).

European Commission (2011) A New Response to a Changing Neighbourhood: A review of European Neighbourhood Policy (25/05/2011), COM (2011) 303, Brussels.

European Commission (2015) "ENP Country Progress Report 2014 - Ukraine" https://ec.europa.eu/commission/presscorner/detail/en/MEMO $15 \quad 4679$ (05.01.2021).

Ferreira-Pereira, L.C. \& Vieira, A.V.G. (2015) “Ukraine in the European Union's Partnership Policy: A Case of Institutionalized Ambiguity”, European Politics and Society, 16(2): 143-158.

Grant, C. (2011) “A new neighbourhood policy for the EU”, Centre for European Reform Policy Brief, March, pp.1-13.

Official Journal of European Union (2014) "Association Agreement between the European Union and its Member States, of the one part, and Ukraine, of the other part", http://trade.ec.europa.eu/doclib/docs/2016/november/tradoc 155103.pdf (05.01.2021).

Pridham, G. (2014) "EU/Ukraine Relations and the Crisis with Russia, 2013-14: A Turning Point", The International Spectator: Italian Journal of International Affairs, 49(4): 53-61. 
Prodi, R. (2002) A Wider Europe -A Proximity Policy as the Key to Stability, Brussels, $6^{\text {th }}$ ECSA-World Conference, 5-6 December.

Sasse, G. (2008) “The European Neighbourhood Policy: Conditionality Revisited for the EU’s Eastern Neighbours", Europe-Asia Studies, 60(2): 295-316.

Sasse, G. (2010) “The ENP and the EU's Eastern Neighbours: Ukraine and Moldova as Test Cases”, in Whitman, R.G. \& Wolff, S. (eds) (2010), The European Neighbourhood Policy in Perspective Context, Implementation and Impact, London: PALGRAVE MACMILLAN, pp.181-205.

Smith, K.E., (2005) “The outsiders: the European neighbourhood policy”, International Affairs, 81(4): 757-773.

Solonenko, I. (2006) "European Neighbourhood Policy- The Perception of Ukraine”, in Overhaus, M., Maull, H.W. \& Harnisch S. (eds) (2006) Foreign Policy in Dialogue: The New Neighbourhood Policy of the European Union Perspectives from the European Commission, France, Germany, Poland, Ukraine and Moldova, 7(19): 44-51.

Tonra, B. (2010) "Identity Construction through the ENP: Borders and Boundaries, Insider and Outsiders", in Whitman, R.G. \& Wolff, S. (eds) (2010) The European Neighbourhood Policy in Perspective Context, Implementation and Impact, London: PALGRAVE MACMILLAN, pp.5172.

Whitman, R.G. \& Wolff, S. (2010), "Much Ado About Nothing? The European Neighbourhood Policy in Context", in Whitman, R.G. \& Wolff, S. (eds) (2010) The European Neighbourhood Policy in Perspective Context, Implementation and Impact, London: PALGRAVE MACMILLAN, pp.326. 